\title{
Identification of microbial contaminants in drinking water samples of Ahmedabad using PCR
}

\author{
Rohi T. Bhatt \\ Department of Biotechnology, Government Science College, K. K. Shastri Educational \\ Campus, Maninagar, Ahmedabad-380008 (Gujarat), India

\section{Manisha A. Nagwadiya} \\ Department of Biotechnology, Government Science College, K. K. Shastri Educational \\ Campus, Maninagar, Ahmedabad-380008 (Gujarat), India

\section{Sheji Chandran} \\ Department of Biotechnology, Government Science College, K. K. Shastri Educational \\ Campus, Maninagar, Ahmedabad-380008 (Gujarat), India \\ Bhupesh Yagnik* \\ Department of Biotechnology, Government Science College, K. K. Shastri Educational \\ Campus, Maninagar, Ahmedabad-380008 (Gujarat), India
}

${ }^{*}$ Corresponding author. E-mail: yagnikbn@hotmail.com

\begin{abstract}
:
Quality of drinking water is one of the greatest anxiety of water consumers with contamination of different pathogenic microorganisms especially fungi and bacteria. Water-borne pathogen contamination in water resources and related diseases are a major water quality concern throughout the world. A motivation for this study was the numerous reports about these contaminations of drinking water and the associated diseases. Water samples were collected from various locations of Ahmedabad in February 2017. The samples were analyzed by $16 S$ rDNA PCR and ITS rDNA PCR since the DNA sequence polymorphisms in the 16S ribosomal DNA and ITS rDNA can be used for the identification of bacterial and fungal species respectively. The PCR amplicons were obtained for each water samples, were sequenced and the species identity was determined using NCBI-BLAST. Bacterial species of Aeromonas, Citrobacter and E. coli along with two fungal species were obtained from municipal water supplies and parab waters. Species of AspergilIus and Penicillium represented the most common fungi in municipal water supplies. This is the first report of molecular study from drinking water facilities of Ahmedabad. This study has clearly revealed that currently, the microbiological quality of the water is inferior for drinking purpose due to bacterial and fungal contamination. This study also showed the potential PCR based identification as a rapid technique for identifying microorganisms in drinking water samples.
\end{abstract}

Keywords: $16 \mathrm{~S}$ rDNA sequencing, ITS rDNA, Metagenomics, PCR, Water microbiology

\section{Article Info}

DOI:10.31018/jans.v10i3.1796

Received: June 13, 2018

Revised: July 5, 2018

Accepted: July 27, 2018

\section{How to Cite}

Bhatt, R.T. et al. (2018). Identification of microbial contaminants in drinking water samples of Ahmedabad using PCR. Journal of Applied and Natural Science, 10(3): 905 - 909

\section{INTRODUCTION}

Human population growth wields several and various pressures on the quality and the quantity of drinking and fresh water resources and its access. Safe drinking water remains inaccessible to several millions people in the globe. Water contamination has a long presence in human history, with descriptions in the Sushruta Samhita about waterborne diseases resembling cholera in an Indian text written in Sanskrit as early as 500-400 B.C. (Colwell, 1996). Contamination of drinking water due to natural and manmade contaminants is frequently reported in developing countries where mainstream of the inhabitants survive in countryside and uptown areas with meager hygiene and waste clearance practices. Presence of pathogen- ic protozoa, bacterial and viruses entering in drinking water supplies through human and animal fecal matter are the cause of major disease outbreaks (Dore, 2015). Failure on regulation and management of treated drinking water and its sources eventually leads to environmental degradation. In developing countries, poor water quality is the most important risk of child mortalities which are mainly through infectious diarrhea. In India, about $10 \%$ of the countryside and city populations do not have access to usual safe drinking water and several others are threatened (Suthar, 2011). The quality of drinking water is ascertained by its microbiological examination. The maximum threat from microbes (coliform) in water is related to drinking water contaminated with human or animal excreta. Detection of the Gram-negative, non- 
spore-forming bacilli that ferment lactose with the production of acid and gas from the water sample points towards fecal contamination (American Public Health Association, 1998). However, the cultivation-based method being time consuming, attempts are focused on fast and reliable way of detecting water-borne pathogens. With the recent development of Polymerase Chain Reaction (PCR) and other in vitro enzymatic amplification techniques for target gene sequences, the direct detection of low levels of human pathogens in environmental samples becomes more plausible, practical, and economically feasible (Persing et al., 1993; Sobsey et al., 1996). Seema Tharannum et al. (2009) reviewed molecular methods for detecting coliforms in water, that avert long incubation, interference by antagonistic organism, lack of specificity and losing non-culturable microorganisms. A motivation of this study was the numerous reports about these contaminations of drinking water and the associated diseases. The goal of our study was to analyze the drinking water quality of various sources from different regions of Ahmedabad with the use of rapid and highly sensitive molecular biological technique based on 16s rDNA PCR and sequence analysis.

\section{MATERIALS AND METHODS}

Collection of water samples: The water samples were collected during February 2017 from different sites of Ahmedabad in white plastic containers, previously rinsed with distilled water and sterilized by autoclaving at $121^{\circ} \mathrm{C}$ for 15 mins. The commercially sold water bottles were purchased from store and similar to other samples, were stored in a refrigerator at $4^{\circ} \mathrm{C}$ till further processing. Details of the samples are given in Table 1.

Identification of bacteria by PCR and $16 \mathrm{~S}$ rDNA sequencing: The water samples were analyzed directly for detecting DNA without culturing for bacteria. Genomic DNA from the water samples was isolated according to the protocol of Sambrook et al. (2001). The DNA obtained was quantified determining UV absorbance method and was suitably diluted to final concentration of $50 \mathrm{ng} . \mathrm{\mu L}^{-1}$ of DNA. Amplification of $16 \mathrm{~S}$ rDNA was performed on Swift Maxi Thermal Cycler (ESCO, USA) with universal primer set $16 \mathrm{~S}$ (FP) (5'-AGA GTT TGA TCC TGG CTC AG- 3') and 16S (RP) (5'-AAG GAG GTG ATC CAG CCG CA- 3') (Stackebrandt and Goebel, 1994) in $25 \mu \mathrm{L}$ of reaction mixture containing $1 \mathrm{X}$ Taq buffer, $100 \mu \mathrm{Mol} \mathrm{L}{ }^{-1}$ dNTPs mix, $3.0 \mathrm{mMol} \mathrm{L}{ }^{-1} \mathrm{MgCl}_{2}$, $10 \mu \mathrm{g}$ BSA, $10 \mathrm{pMol}$ each primer, $0.5 \mathrm{U}$ of Taq DNA polymerase and $50 \mathrm{ng}$ of template DNA. The thermal cycling conditions consisted of an initial denaturation at $94^{\circ} \mathrm{C}$ for $2 \mathrm{~min}, 35$ amplification cycles of $94{ }^{\circ} \mathrm{C}$ for $1 \mathrm{~min} 10 \mathrm{~s}, 48{ }^{\circ} \mathrm{C}$ for $30 \mathrm{~s}, 72^{\circ} \mathrm{C}$ for 2 min $10 \mathrm{~s}$ and a final polymerization step of $72^{\circ} \mathrm{C}$ for 6 min $10 \mathrm{~s}$. The final PCR product was resolved in $2 \%$ Agarose gel, excised and purified with in house elution kit. The cycle sequencing reaction was performed with 20-30 ng of purified amplicon using the ABI PRISM BigDye Terminators $\mathrm{v} 1 \cdot 1$ cycle sequencing kit according to the manufacturer's instruction (Applied Biosystems, Foster city, CA).

The purified products were sequenced bidirectionally to obtain complete coverage of the gene. The sequences were edited, and compared with GenBank sequences by Basic Local Alignment Search Tool (BLAST) analysis and accession number assigned. Nucleotide sequence similarities were determined using the NCBI or EMBL databases, and sequence identity vis-à-vis the bacterial identity was established by closest match (Altschul et al., 1990). The 16s rDNA sequences were submitted in GenBank.

Identification of fungi by ITS PCR and ITS rDNA sequencing: He Internally Transcribed Spacer (ITS) region of the three isolates were amplified using the primers ITS 6 (5'GAAGGTGAAGTCGTAACAAGG-3') and ITS 4 (5'-TCCTCCGCTTATTGATATG-3') (White et al., 1990). The PCR was performed in $25 \mu \mathrm{L}$ reaction volumes with each reaction mixture containing 10X PCR buffer, $1.5 \mathrm{mM} \mathrm{MgCl}_{2}, 20$ pMole each of primers, $10 \mathrm{mM}$ each of the dNTPs, and 1.5 units of Taq polymerase. Amplification was performed in an automated thermal cycler Swift Maxi Thermal Cycler (ESCO, USA) and the programme consisted of Initial denaturation at $94^{\circ} \mathrm{C}$ for $3 \mathrm{~min}$ followed by 34 cycle repeats involving denaturation at $94{ }^{\circ} \mathrm{C}$ for $30 \mathrm{~S}$, annealing $55^{\circ} \mathrm{C}$ for $30 \mathrm{~S}$ and synthesis at $72^{\circ} \mathrm{C}$ for $1 \mathrm{~min}$ and a final extension at $72^{\circ} \mathrm{C}$ for $10 \mathrm{~min}$. The amplified products were analyzed on ethidium bromide $(2 \%)$ stained along with size standard 500 bp ladder (Genei, Bangalore, India), visualized under UV and photographed using Transilluminator (Alpha Innotech corporation). The sequences were edited and compared with GenBank sequences by BLAST analysis and accession number assigned. Nucleotide sequence similarities were determined using the NCBI or EMBL databases, and sequence identity vis-à-vis the bacterial identity was established by closest match (Altschul et al., 1990). The ITS rDNA sequences were submitted to GenBank.

\section{RESULTS}

Identification of bacteria by PCR and 16S rDNA sequencing: Water DNA samples were amplified using 16S rDNA PCR. A 1500 bp amplicons were obtained for municipal supply water and parab water collected from Shah-e-Alam area, whereas all other water DNA samples showed no amplification for 16S PCR. All the PCR amplicons were then sequenced.

Identification of fungi by ITS PCR and ITS rDNA sequencing: Water DNA samples were 
Bhatt, R.T. et al. / J. Appl. \& Nat. Sci. 10 (3): 905 - 909 (2018)

Table 1. Water samples collected from the adjoining areas for the present study.

\begin{tabular}{llll}
\hline No. & Sample* $^{*}$ & \multicolumn{1}{c}{ Location* $^{*}$} & Date of collection \\
\hline 1. & BL & General Store, Vejalpur, Ahmedabad & $06-02-2017$ \\
2. & BF & Parlour, Maninagar, Ahmedabad & $06-02-2017$ \\
3. & KN & General Store, Vejalpur, Ahmedabad & $06-02-2017$ \\
4. & Slum area water & Shah-e-Alam, Ahmedabad & $06-02-2017$ \\
5. & This Institute & Government science College, Maninagar, Ahmedabad & $06-02-2017$ \\
6. & Municipal school water & Municipal School, \# 6, Khokhara, Ahmedabad & $06-02-2017$ \\
7. & Parab-1 & Manekbaug, Ahmedabad & $06-02-2017$ \\
8. & Parab-2 & Shah-e-Alam, Ahmedabad & $06-02-2017$ \\
\hline
\end{tabular}

*Encoded

Table 2. Sequence of rDNA from uncultured microbes in water samples

\begin{tabular}{|c|c|c|c|}
\hline No & Accession No. (Date) & $\begin{array}{l}\text { Description } \\
\end{array}$ & Match \\
\hline 1 & $\begin{array}{l}\text { MG983985 } \\
(24-F E B-2018)\end{array}$ & $\begin{array}{l}\text { Uncultured bacterium clone RBC } 16 \mathrm{~S} \text { ribosomal RNA } \\
\text { gene, partial sequence } \\
\text { (1,464 bp linear DNA) }\end{array}$ & $\begin{array}{l}\text { Citrobacter freun- } \\
\text { dii } 16 \mathrm{~S} \text { (partial), } \\
98 \%\end{array}$ \\
\hline 2 & $\begin{array}{l}\text { MG983986 } \\
(24-F E B-2018)\end{array}$ & $\begin{array}{l}\text { Uncultured bacterium clone RBE } 16 \mathrm{~S} \text { ribosomal RNA } \\
\text { gene, partial sequence } \\
\text { (1,390 bp linear DNA) }\end{array}$ & $\begin{array}{lr}\text { Escherichia } & \text { coli } \\
\text { BM16 } & 16 \mathrm{~S} \\
\text { (complete), } & 100 \%\end{array}$ \\
\hline 3 & $\begin{array}{l}\text { MG881864 } \\
(01-F E B-2018)\end{array}$ & $\begin{array}{l}\text { Uncultured fungus isolate MNP internal transcribed } \\
\text { spacer } 1 \text {, partial sequence; } 5.8 S \text { ribosomal RNA gene } \\
\text { and internal transcribed spacer } 2 \text {, complete sequence; } \\
\text { and large subunit ribosomal RNA gene, partial se- } \\
\text { quence. ( } 835 \text { bp linear DNA) }\end{array}$ & $\begin{array}{l}\text { Penicillium } \\
\text { cvjetkovicii NRRL } \\
58240,99 \%\end{array}$ \\
\hline 4 & $\begin{array}{l}\text { MG881865 } \\
(01-F E B-2018)\end{array}$ & $\begin{array}{l}\text { Uncultured fungus isolate MNA internal transcribed } \\
\text { spacer } 1 \text {, partial sequence; } 5.8 S \text { ribosomal RNA gene } \\
\text { and internal transcribed spacer } 2 \text {, complete sequence; } \\
\text { and large subunit ribosomal RNA gene, partial se- } \\
\text { quence. ( } 587 \text { bp linear DNA) }\end{array}$ & $\begin{array}{l}\text { Aspergillus flavus, } \\
98 \%\end{array}$ \\
\hline
\end{tabular}

amplified using ITS rDNA PCR. Approximately $800 \mathrm{bp}$ amplicons were obtained for municipal supply water and parab water collected from Shah -e-Alam area, whereas all other water DNA samples showed no amplification for ITS PCR. All PCR amplicons were then sequenced.

Result of sequence analysis: Three different bacterial sequences and two different fungal sequences were obtained from these amplicons. The detail of these sequences is shown below and submissions SUB3610177 and SUB3556940 (NCBI, 2018) are listed in Table 2. An amplicon with following bacterial sequence (not submitted) was also obtained from one of the water samples. This sequence identified as that from Aeromonas, known to be of soil origin.

>Bacterial Sequence 1 Size: 1135 bp showed 96 $\%$ similarity to Aeromonas hydrophila $16 \mathrm{~S}$ ribosomal RNA gene with an E. value 0 .

GGGGTTGGTAAAAGGCCAC-

TTTTTCAGGCCGAGGGAAGGAAAAGGGTCCA GTTAGGCTTATTATTCCGGCCGGGACTGTGG ACCGTTTACTTGGCAGAAAGAAAGCACCCGG GCTAAATTTCCGTGGCCAGCCAGCCGGCGGT AATTACGGGAGGGTGCCAAGGCGTTTATTGG GAAATTCCTGGGGCGTAAAGGCGCACGCCGG GCGGTTGGGATAAAGTTAGAATGTGAAAAGC CCCCGGGCTTCAACCCTGGGAAATGGCATTT AAAAACTGTCCCAGCCTAGAGTTCTTGTAGAG GGGGGGTAGAATTCCCAGGTGTAGCGGGTGA AATGCGTAGAGATCTGGAGGAATACCGGTGG
CGAAGGCGGCCCCCTGGACAAAGACTGACGC TCAGGTGCGAAAGCGTGGGGAGCAAACAGGA TTAGATACCCTGGTAGTCCACGCCGTAAACGA TGTCGATTTGGAGGCTGTGTCCTTGAGACGTG GCTTCCGGAGCTAACGCGTTAAATCGACCGCC TGGGGAGTACGGCCGCAAGGTTAAAACTCAAA TGAATTGACGGGGGCCCGCACAAGCGGTGGA GCATGTGGTTTAATTCGATGCAACGCGAAGAA CCTTACCTGGCCTTGACATGTCTGGAATCCTG CAGAGATGCGGGAGTGCCTTCGGGAATCAGA ACACAGGTGCTGCATGGCTGTCGTCAGCTCGT GTCGTGAGATGTTGGGTTAAGTCCCGCAACGA GCGCAACCCCTGTCCTTTGTTGCCAGCACGTA ATGGTGGGAACTCAAGGGAGACTGCCGGTGA TAAACCGGAGGAAGGTGGGGATGACGTCAAG TCATCATGGCCCTTACGGCCAGGGCTACACAC GTGCTACAATGGCGCGTACAGAGGGCTGCAA GCTAGCGATAGTGAGCGAATCCCAAAAAGCGC GTCGTAGTCCGGATTGGAGTCTGCAACTCGAC TCCATGAAGTCGGAATCGCTAGTAATCGCAAA TCAGAATGTTGCGGTGAATACGTTCCCGGGCC TTGTACACACCGCCCGTCACACCATGGGAGTG GGTTGCACCAGAAGTAGATAGCTTAACCTTCG GGAGGGCGTTTACCACGGTGTGATTCATGACT GGGGTGAAGTCGT

\section{DISCUSSION}

Waterborne pathogens are a global concern for public health worldwide. Since pathogens in water are still a major cause of severe illness and mortality, the control, monitoring and implementation of 
regulations for water quality are in urgent need and must incorporate more effective microbiological monitoring, pathogen detection and health risk assessment in order to reach the goal of pathogen -free water. Microbiological drinking water safety is traditionally monitored mainly by bacterial parameters that indicate fecal contamination. The presence of coliforms shows the danger of fecal pollution and a consequent hazard of contracting a disease through pathogenic organisms. Nonetheless, the disease-causing organisms (pathogens) mostly transmitted via drinking water are predominantly of fecal origin. Conventional culture-based microbiological water quality monitoring techniques take a long time (several days), and usually a small (typically $100 \mathrm{~mL}$ ) volume of water tested, and subject to survival of the microorganisms, which gives rise to inadequate detection limits with regard to drinking water safety.

The bacteria identified in this study are known to present in all sorts of environment of human involvement, majority of them are opportunistic pathogenic to human as well as animals and fishes. This is the first report of molecular identification of drinking water sources from Ahmedabad.

Waterborne pathogen detection and quantitation by nucleic acid amplification and hybridization methods has advanced greatly in the last decade, and has been successfully applied to pathogen detection in field samples, appears to be a most promising technology for the future. Drancourt et al. (2000) reported the usefulness of 16S rRNA gene sequencing as a tool in microbial identification from drinking water samples. Several studies have shown that microbial pathogens, such as Salmonella, E. coli, S. faecalis, and enteroviruses are relatively stable in chemically treated drinking water supplies (Bitton et al. 1983; Schijven and Hassanizadeh, 2000; Pang et al., 2004, Dehghan et al., 2014 and Rosselli et al., 2016) by PCR and using rRNA sequence analysis and PCR from various drinking water sources. Although the most promising tool to detect water contamination, molecular methods are still inadequate for real time monitoring, unable to distinguish viable and nonviable organisms, and are marred by the presence of PCR-inhibitory substances (Samendra et al., (2014).

The parab water analyzed in this study has clearly shown that they are loaded with indicator organisms $E$. coli linking to fecal pollution and seem to have seeped into the water body via human activities and agricultural runoff. This study reveals need of serious control activities around the water supplies to prevent microbial contaminants which have public health implications. This study also suggests routine water quality survey and monitoring programs to estimate the pollution level, rate at which additional pollutants are getting added and the causes of pollution. The presence of pathogens such as $E$. coli in these samples underpins the failure of the water purification efforts and especially the operations of the water treatment and transport.

Recently, Suthar (2011) reported a wide range of pathogenic bacteria in potable water samples from some rural habitations of Northern Rajasthan, India. A total of ten bacterial species were reported in his study, includes E. coli, Pseudomonas aeruginosa, Klebsiella sp., Enterobacter aerogenes, Proteus vulgaris, Alcaligenes faecalis, Bacillus cereus, Staphylococcus aureus, Streptococcus lactis, and Micrococcus luteus, from the potable water samples from this region (from $73.1 \%$ of the villages / towns).

The presence of pathogenic organisms that can pose severe health risks to consumers in general and more in infants and aged individuals. These opportunistic pathogens may harbor multiple drug resistance determinants pose significant health hazards to consumers, especially those whose immune systems are compromised. This study has clearly revealed that currently, the microbiological quality of water consumed in Ahmedabad city is unsafe for potable use at a few places and to some extent for recreational activities due to microbial contamination.

The disease outbreaks by such contamination are governed by multiple factors. The infrastructure, chemical coat of water storage pipes and the architecture of the systems could enhance or inhibit the growth of microbial growth as communities in drinking water systems causing an outbreak. Breaks or leaks could lead to low pressure events and when repaired, pathogens could enter into the systems (Ingerson-Mahar et al., 2012, Hunter et al., 2005). Inadequate water treatment or interrupted disinfection of groundwater along with changes in weather are the key factors that contributes to outbreaks, since it introduces contaminants into water sources by runoff from either a heavy rainfall or flooding. Moreover, changes in temperature can alter the dynamic of microbes in pipes since planktonic microorganisms may become trapped into biofilms, while pathogens on biofilm may be released in flowing water. The identification and detection of microbial contaminants in drinking water must continue to be a high priority for assessing the risks from and managing the microbial quality of drinking water supplies.

\section{Conclusion}

The PCR-based detection revealed presence of microbial genomic traces originated from fecal and soil origin. Although, presence of DNA fragments from bacterial and fungi is not enough to denounce the water sample for drinking purpose. Nevertheless, it warrant careful examination for presence of live coliform bacteria and focus on raw water quality at the purification and supplied 
levels. The prevalence of bacterial species detected by metagenomics studies, suggests coliform strain with different genomic sequence than conventionally known. Conclusion The present study analyzed various drinking water samples of Ahmedabad city using 165 rDNA based molecular methods and detected the presence of microorganisms indicative of contamination by bacterial pathogens. In this study, we have used several water sources, such as municipal water, marketed bottled water, and parab water. The results on the detection of potentially pathogenic bacteria in the drinking water distribution system had shown the presence of indicator bacteria $E$. coli and also other opportunistic bacteria, such as Aeromonas hydrophila and Citrobacter freundii emphasizing those drinking water systems, particularly with stagnant water sections, defective ozonization and storage could be the source of these contaminations. Detection of fungal contaminants is presumed to have origin from soil and handling, are not a potential threat to safety, until within acceptable count.

\section{REFERENCES}

1. Altschul SF, Gish W, Miller W, Myers EW, Lipman DJ. (1990) Basic local alignment search tool. J. Mole. Biol.: 215(3): 403-10.

2. American Public Health Association (1998) Bacteriological Analytical Manual (8th Edn), Food and Drugs Administration, USA.

3. Bitton G, Dutton RJ, Foran JA. (1983) New rapid technique for counting microorganisms directly on membrane filters. Stain Technol. 6: 343-6.

4. Colwell, R. R. (1996) Global climate and infectious disease: the cholera paradigm. Science 274:20252031.

5. Dehghan Fatemeh, Zolfaghari Mohammad Reza, Arjomandzadegan Mohammad, Kalantari Salomeh, Ahmari Gholam. (2014) Rapid detection of coliforms in drinking water of Arak city using multiplex PCR method in comparison with the standard method of culture (Most Probably Number). Asian Pacific Journal of Tropical Biomedicine, 4(5): 404-409.

6. Dore M.H. (2015) Global Drinking Water Management and Conservation Optimal Decision-Making. 1st Edn. Springer International Publishing, Switzerland, pp.3-30

7. Drancourt M, Bollet C, Carlioz A, Martelin R, Gayral JP, Raoult D. (2000) 16S ribosomal DNA sequence analysis of a large collection of environmental and clinical unidentifiable bacterial isolates. J Clin Microbiol. 10: 3623-30

8. Hunter P.R., Chalmers R.M., Hughes S., Syed Q. (2005) Self-reported diarrhea in a control group: A strong association with reporting of low-pressure events in tap water. Clin. Infect. Dis. 40: e32-e34. doi: $10.1086 / 427750$.

9. Ingerson-Mahar M., Reid A. (2012) Microbes in Pipes: The Microbiology of the Water Distribution System A Report on an American Academy of Microbiology Colloquium. ASM Academy; Boulder, CO, USA: pp. 26

10.NCBI (2018) 'National Center for Biotechnology Information', National Institutes of Health, USA. Retrieved June, 12 2018. https://www.ncbi.nlm.nih.gov/search/

11.Pang, X., D. Zhou, Y. Song, D. Pei, J. Wang, Z. Guo, and R. Yang. (2004). Bacterial mRNA purification by magnetic capture-hybridization method. Microbiol. Immunol. 48: 91-96.

12.Persing, D. H. (1996). PCR Protocols for Emerging Infectious Diseases-A Supplement to Diagnostic Molecular Microbiology: Principles and Applications. Washington, D.C.: ASM Press.

13.Rosselli Riccardo, Ottavia Romoli, Nicola Vitulo, Alessandro Vezzi, Stefano Campanaro (2016) Direct 16S rRNA-seq from bacterial communities: a PCRindependent approach to simultaneously assess microbial diversity and functional activity potential of each taxon, Scientific reports pp 1-7, DOI: 10.1038/ srep32165 1

14.Sambrook, J.; Russel, D.W. (2001) Molecular cloning: a laboratory manual. 3rd Edn. New York: Cold Spring Harbor Laboratory Press, pp 2344.

15.Samendra PS, Masaaki K, Charles PG, and lan LP (2014). Rapid detection techniques for monitoring microorganisms in water, Biosensor $\mathrm{J}$ 3: 109. doi: 10.4172/2090-4967.1000109.

16.Schijven, J. F., G. J. Medema, A. J. Vogelaar, and S. M. Hassanizadeh. (2000). Removal of microorganisms by deep well injection. J. Contam. Hydrol. 44: 301-327.

17.Seema Tharannum, Sarah Sunitha, Nitya J. (2009) Molecular conformation of the presence of coliform in drinking water using polymerase chain reaction, Kathmandu University Journal of Science, Engineering and Technology 5, pp 130-136.

18.Sobsey, M. D., K. J. Schwab, R. De Leon, and Y.-S. C. Shieh. (1996). Enteric Virus Detection in Water by Nucleic Acid Methods. Final report. Denver, Colo.: American Water Works Association Research Foundation.

19.Stackebrandt, E. and Goebel, B. (1994) Taxonomic Note: A Place for DNA-DNA Reassociation and 16S rRNA Sequence Analysis in the Present Species Definition in Bacteriology. International Journal of Systematic Bacteriology, 44: 846-849.

20.Suthar S (2011) Contaminated drinking water and rural health perspectives in Rajasthan, India: an overview of recent case studies. Environmental Monitoring and Assessment. 173: 837-849

21.White TJ, Bruns T, Lee S, Taylor J (1990) Amplification and direct sequencing of fungal ribosomal RNA genes for phylogenetics. In: PCR Protocols: a guide to methods and applications. (Innis MA, Gelfand DH, Sninsky JJ, White TJ, Eds). Academic Press, New York, USA: pp 315-322. 